\title{
Türkiye'de Tekerlekli Sandalye Kullanan Ortopedik Engelli Bireylere Ağız ve Diş Sağlığı Hizmetleri Sunumuna İlişkin Model Oluşturma
}

\author{
Derya ŞAHİN ${ }^{*}$, Samira ETESAMINIA²
}

1 Üsküdar Üniversitesi, Sağlık Bilimleri Enstitüsü, Sağlık Yönetimi Anabilim Dalı, İstanbul, Türkiye

2 Marmara Üniversitesi, Sağlık Bilimleri Enstitüsü, Sağlık Yönetimi Anabilim Dalı, İstanbul, Türkiye

$\begin{array}{ccc}\text { Geliş Tarihi } & \text { Kabul Tarihi } & \text { Yayın Tarihi } \\ 16.03 .2021 & 07.07 .2021 & 31.12 .2021\end{array}$

Özet: : Çalışma, Türkiye'de tekerlekli sandalye kullanan ortopedik engelli bireylerin Ağız ve Diş Sağlığı Hizmetleri sunumunda yaşadıkları sorunların çözümlerine ilişkin model geliştirilmesi amacıyla hazırlanmıștır. Çalışmada, konuyla ilgili ulusal ve uluslararası yayınlanmış makaleler, Türkiye'de engellilere yönelik düzenlenen anket sonuçları, araştırma raporları, yasa ve yönetmeliklerdeki engellilerle ilgili maddeler, gönüllü kuruluşlar ve dernek çalışmaları ile mevcutta uygulanan sağlı hizmetlerine ilişkin bilgilerin yer aldığı literatür incelenmiş, biri kamu diğeri özel sağlık kuruluşunda çalışan iki diş hekimi ile görüşme yapılmıştır. Ayrıca TDB tarafından yayınlanan istatistik verileri ile Türk Diş Hekimlerine yönelik mevzuat da incelenmiștir. Tekerlekli sandalye kullanan ortopedik engelli bireylerin Ağız ve Diş Sağlı̆̆ Hizmetlerine ilişkin en önemli sorunun toplum genelindeki farkındalık ve hassasiyet düzeyinin düşük olmasıyla ilişkili olduğu belirtilebilir. Model önerisinde; engelli bireylerin sorunlarına ilişkin farkındalığı artmış bir toplumda, birinci basamağa entegre edilmiş Ağız ve Diş Sağlı̆̆ı Hizmetleri başta olmak üzere multidisipliner bir yaklaşımla tüm yaşam alanlarında, konuya ilişkin yapılacak düzenlemelerle engelli bireylerin Ağız ve Diş Sağlı̆̆ Hizmetlerinde karşılaştıkları sorunların büyük oranda çözülerek, hizmetlerin etkin ve verimli hale getirilebileceği belirtilmektedir.

Anahtar kelimeler: Engelli, Ortopedik Engelli Birey, Ağız ve Diş Sağlığı Hizmetleri

\section{Wheel Chair Turkey in The Individuals with Disabilities Using Orthopaedic, Dental Health Services Building a Model of Presentation}

\begin{abstract}
The study was prepared in Turkey wheelchair users orthopaedic disabilities of Oral and Dental Health Services to create a model for the solution of problems faced in the content presented. In the study, national and international articles published on the subject, the survey results held for the disabled in Turkey, research reports, articles about people with disabilities in laws and regulations, voluntary organizations and associations working with a review of literature where the information related to applied health services available, which included public and private health Interviews were held with two dentists working in the establishment. In addition, the statistical data published by TDB and the legislation for Turkish Dentists were also examined. It can be stated that the most important problem related to Oral and Dental Health Services of orthopedically disabled individuals using wheelchairs is related to the low level of awareness and sensitivity in the general society. In the model proposal; In a society with increased awareness of the problems of people with disabilities, with a multidisciplinary approach, especially Oral and Dental Health Services integrated into primary care, the problems faced by disabled individuals in Oral and Dental Health Services can be solved to a large extent with the arrangements to be made on the subject, and it is stated that services can be made effective and efficient.
\end{abstract}

Keywords: Disabled, Orthopedically Handicapped Individual, Oral and Dental Health Services

\begin{tabular}{lll}
\hline * Sorumlu yazar & Şahin D 0000-0002-6668-5888 & Etesaminia S 0000-0003-0357-2330 \\
$\begin{array}{l}\text { Derya ŞAHIN } \\
\text { deryademir2309@gmail.com }\end{array}$ & &
\end{tabular}




\section{GíRiş}

Çalışma, Türkiye'de tekerlekli sandalye kullanan ortopedik engelli bireylere Ağız ve Diş Sağlı̆̆ Hizmetleri (ADSH) sunumuna ilişkin model geliştirilmesi amacıyla hazırlanmıştır. Model geliştirme ihtiyacının temel ortaya çıkış nedenine baktığımızda; Türkiye'de dezavantajlı gruplar arasinda yer alan engellilerin ADSH alımında yaşadıkları sorunlara ilişkin çözümlere ihtiyaç duyulduğu görülmektedir. Ancak uygulanabilir ve sürdürülebilir bir model oluşturabilmek için konuyu daha geniş bir açıdan ele almak faydalı olacaktır. Bu bağlamda toplumun; eğitim, siyaset, ekonomi, bilim, teknoloji, sosyal, kültürel, sanatsal ve sportif faaliyetlerinin tamamını gerçekleştirebilmesi için öncelikle sağlıklı bireylere ihtiyacı vardır. Özellikle dünyaca içinde bulunduğumuz; yeni tip koronavirüsün yol açtığı Covid-19 hastalığı, bölgesel olmaktan çıkmış, küresel anlamda etkisini gösteren bir pandemi vakasına dönüşerek, neredeyse dünyadaki tüm sosyal ve ekonomik faaliyetleri durma noktasına getiren bir süreci başlatmıştır. Bu açıdan, Dünya Sağlık Örgütü tarafından yapılan sağlık kavramının tanımına baktığımızda; "yalnızca hastalık veya sakatlığın olmaması durumu değil, fiziksel, sosyal ve ruhsal yönden tam bir iyilik halidir." ifadesinin tam olarak karşılık bulduğu görülmektedir. Dolayısıyla toplum sağlığı ve konumuz olan tekerlekli sandalye kullanan ortopedik engelli bireylerin ADSH'ne ilişkin model önerisi oluşturulurken, sadece ağız ve diş sağlığıyla ilgili hizmetler değil; eğitim, sosyokültürel faaliyetler, yasa-yönetmelikler, merkezi ve yerel yönetimlerin yaklaşımları gibi unsurlar da dikkate alınmıştır.

Çalışma için ulusal ve uluslararası yayınlanmış makaleler, engellilere yönelik yapılan anket sonuçları, araştırma raporları, yasa ve yönetmelikler, mevcutta uygulanan sağllk hizmetleri bilgilerine ilişkin literatür incelenmiş, 2 diş hekimi ile görüşme yapılmış, TDB (Türk Diş hekimliği Birliği) tarafından yayınlanan istatistiki veriler ile diş hekimleriyle ilgili mevzuat incelenmiştir. Yapılan bu incelemeler sonucunda hedeflenen; Türkiye'de tekerlekli sandalye kullanan ortopedik engelli bireylerin
ADSH ile ilgili yaşadıkları sorunların çözümüne ilişkin kaynakların etkin ve hakkaniyetli kullanımı dikkate alınarak ve multidisipliner bir yaklaşım benimsenerek, detaylı araştırmalarla daha da geliștirilebilecek bir model önerisi oluşturulmuştur.

\section{GENEL BİLGÍLER}

Birleşmiş Milletler Genel Kurulu' nun 13 Aralık 2006 tarihli ve A/RES/61/106 sayılı kararıla kabul edilmiş ve 3 Mayıs 2008 tarihinde yürürlüğe girmiş olan, Türkiye tarafından ise 30 Mart 2007 tarihinde imzalanarak, 3 Aralık 2008 tarih ve 5825 sayılı kanunla uygun bulunan Birleşmiş Milletler Engelli Hakları Sözleşmesi' ne göre "kişisel ya da sosyal yaşantısında kendi kendine yapması gereken işleri herhangi bir noksanlık sonucunda yapamayanlar" engelli olarak tanımlamaktadır (Resmi Gazete, 2009). Ortopedik engelli ise; doğum öncesi, doğum sırası ve doğum sonrası dönemde herhangi bir nedene bağlı olarak iskelet (kemik), kas ve sinir sistemindeki bozukluklar sonucu, bedensel yeteneklerini çeşitli derecelerde kaybeden, toplumsal yaşama uyum sağlama ve günlük yaşamdaki gereksinimlerini karşılamada güçlükleri olan, bu nedenlerle korunma, bakım, rehabilitasyon, danışmanlık ve destek hizmetlerine ihtiyaç duyan kişi; buna yol açan durumlar ise ortopedik engel olarak ifade edilmektedir.

Ortopedik engelli bireyler bedensel, zihinsel, ruhsal sorunlarının yanı sıra toplum algısı ve erişilebilirlik sorunları nedeniyle de eğitim, sağllk, istihdam gibi konularda güçlüklerle karşıllaşmaktadırlar. Özellikle bireysel bakım yeteneği azalan engelli bireyler ağız diş hastalıkları bakımından yüksek risk gurubundadır (Vozza ve ark., 2015). Bu nedenle ağız diş sağlı̆̆ını korumak çok büyük önem taşır. Ancak konuyu sadece ağız ve diş sağlığı olarak değil; ağız sağlığının genel sağlığa etkisi üzerinden değerlendirmek gerekir. Bunun en güncel ve iyi örneklerinden biri olarak Alabama Halk Sağlığı tarafından "Senin Ağzın Senin Sağlığın” adında hazırlanan Ağız Sağlığı Planı 2018-2023 gösterilebilir. Plan hedefleri oldukça kapsayıcı nitelikte olup; sağlık hizmetlerine 
erişimi artırma, mesleki eğitim ve entegrasyon, sağlık okuryazarlığı, veri ve izlem ile önlemeye ilişkin çalışmaları kapsamaktadır (OHCA, 2018). Engelli bireylere firsat eşitliği sağlanmasına yönelik ulusal ve bölgesel düzeyde ADSH'nin ihtiyaca uygun etkin ve verimli sunulabilmesi için geliştirilecek tüm programlarda güvenilir istatistiki verilerin değerlendirilmesi en kritik unsurlar arasında yer almaktadır. Ülkemizde engellilere yönelik yapılan araștırma verilerine baktığımızda; TÜİK Engellilik Oranı 2002 verilerine göre, Türkiye'deki toplam nüfusun \%12,3'ünü engelli bireylerin oluşturduğu görülmektedir. Aynı zamanda çalışmanın odak grubu olan ortopedik engelliler ise toplam engelli nüfusun $\% 1,3$ 'ünü oluşturmaktadır. TÜİK, Engellilerin Sorun ve Beklentileri Araştırması, 2010 verilerine baktığımızda ise engelli bireylerin; oturduğu bina, kaldırım, yaya yolu ve yaya geçidi, kamu binaları, dükkan, market, mağaza ve lokantalar, sinema, tiyatro ve spor tesisleri gibi alanlardaki fiziksel düzenlemelere iliş̧in ciddi sorunlar yaşandığı görülmektedir. TUIK' in engelli bireylerin kamu kurum ve kuruluşlarından beklentilerinin engel türüne göre dağılımı, 2010 verileri de engelli bireylerin \%77 oranında sağlık hizmetleri alanında sorun yaşadıklarını göstermektedir. TÜIKK verilerine ek olarak engelli bireylerin fiziksel çevre düzenlemeleri ile ilgili durumun tespit edilmesine yönelik yapılan bir araştırmada ise Çukurova Üniversitesi yerleşkesinde belirlenen alanlardaki kaldırımlar ve rampalar, yaya yolları, bina girişleri, toplu taşıma durakları, otoparklar, işaret ve işaretlemeler ve yaya geçitleri TS 12576 sayılı Şehir İçi Yollar - Özürlü ve Yaşlılar için Sokak, Cadde, Meydan ve Yollarda Yapısal Önlemler ve İşaretlemelerin Tasarım Kuralları'na göre incelenmiş ve uygunluk düzeyleri saptanmıştır. Araştırma sonucuna göre, yerleșkedeki alan ve mekânlara engelli bireylerin ulaşabilirliği ve kullanabilirliğinde ciddi sıkıntılar bulunduğu ve düzenlemeler yapılması gerektiği belirlenmiştir. $\mathrm{Bu}$ düzenlemeler bireylerin yerleşke hayatı ile bütünleșebilmeleri ve bilgi üretimine etkin katılımları bakımından son derece önemli olup, çalışmaların ilgili kurum ve kuruluşlarca ivedilikle tamamlanması hem yasal bir sorumluluk, hem de toplumun her kesiminin üzerine düşen insani bir görev olduğu belirtilmektedir (Sirel ve ark., 2012).

$\mathrm{Bu}$ istatistiki veriler literatürde verilen araştırma bilgileriyle de desteklenmekte ve özel bakıma ihtiyacı olan engelli bireylerin çok çeşitli sosyodemografik faktörlerden etkilendiği belirtilmektedir (Oredugba ve Akindayomi, 2008). 2016 yılında Konya İl Sağlık Müdürlügü sosyal hizmet uzmanı tarafından engelli bireylere yönelik yapılan bir araştırmada; yüz yüze anket tekniği kullanılarak Konya'da faaliyet gösteren üç farklı hastaneden sağlık hizmeti alan toplam 300 engelli bireyle görüşme yapılmıştır. Verilerin toplanmasında araştırmacılar tarafından geliştirilen "Engelli Birey Sağlık Hizmeti Kullanım Envanteri" kullanılmıştır. Araştırma sonucuna göre; araştırmaya katılan engellilerin, \%52'si sağlık tesislerine ulaşımda sorun yaşadığını ve \%58,3'ü hastane içinde hareket güçlüğü çektiğini belirtmiştir. Araştırma sonuçlarına göre engellilerin; ulaşım, engelli otoparkının kullanılamaması, engellilere yönelik hostes hizmetinin sunulmaması, sağlık tesisi içerisinde hareket güçlüğü yaşama, öncelik hakkının kullanılamaması, sağlık tesislerindeki işlemlerinin başka günlere ertelenmesi gibi problemler ile karşılaştıkları belirlenmiștir (Özata ve Karip, 2017). Benzer bir araştırmada da özel eğitim kurumuna devam etmekte olan 712 yaş arası engelli çocukların ağız ve diş sağlı̆̆ problemleri ebeveyn bakış açısına göre değerlendirilmektir. Veriler, engelli çocuğa sahip 30 anne ile ağız ve diş sağlığını ilgilendiren soruların yer aldığı yarı yapılandırılmış görüşme formu kullanılarak bire bir görüşme yöntemiyle toplanmıştır. Araştırma sonucuna göre, engelli çocukların ciddi anlamda ağız ve diş sağlı̆̆ problemleri olduğu görülmüştür. Aynı zamanda ebeveynler ve özel eğitim kurumları tarafından ağız ve diş sağlığı konularının ihmal edilen bir konu olduğu, hem ebeveynlerin hem de özel eğitim kurumlarının engelli çocukların eğitsel ihtiyaçları yanında ağız ve diş sağlığının korunması ve rahatsızlıkların tedavisi için girişimlerde bulunmaları gerektiği sonucuna varılmıştır (Özyürek ve ark., 2014). Benzer 
şekilde özel bakıma ihtiyacı olan çocuk ve genç yetişkin grubunda yer alan (3-26 yaş arasında) 55 kişi üzerinde yapılan çalışmada deneklerin diş çürüğü prevalansı oldukça yüksek $(\% 53,7)$ olduğu, diyet değişikliği yapılması gerektiği ve ebeveyn eğitimlerine ağırlık verilmesi gerektiği belirtilmektedir (Oredugba ve Akindayomi, 2008).

TDB'nin diş hekimliğinde insan gücü planlaması Ocak, 2020 yayınında yer alan verilere bakıldığında toplam diş hekimi sayısı giderek artmakta ve 1 diş hekimine düşen nüfus ise giderek azalmaktadır. 2019 verilerine bakıldığında ise ülkemizde toplam 38948 diş hekimi olduğu ve 1 diş hekimine düşen nüfusun 2120 olduğu görülmektedir. Avrupa Birliği ülkelerinde diş hekimi başına düşen kişi sayısı ortalama 1500 dür. Diş hekimine gitme sıklığına bakıldığında ise TDB diş hekimliğinde insan gücü Planlaması, Ocak 2020 verilerine göre; gelişmiş ülkelerde başvuru sıklığı yıllık kişi başı 5 olan sayı ülkemizde $0,9^{\prime}$ dur. Mevcut verilerle yapılan hesaplamalara göre, 2028 yılında ülkemizdeki diş hekimi sayısı 90 000'i aşacaktır. O günkü tahmini TÜİK verilerine göre ise Türkiye nüfusu 88645000 civarında olacak ve diş hekimi başına düşen kişi sayısı 970 olacaktır. Belirtilen verilerden yola çıkıldığında; "Bu koşullarda diş hekimine ihtiyacımızın olmadığı görülecektir." ifadesi TDB Diş hekimliğinde İnsan gücü Planlaması Ocak, 2020 yayınında yer almaktadır. Güvenilir kaynaklar tarafından sunulan istatistiki rakamlar, kanıta dayalı veriler kullanılması yoluyla "etkin kaynak kullanımını" sağlamak açısından oldukça önemli bir unsurdur. Türkiye'de tekerlekli sandalye kullanan ortopedik engelli bireylere yönelik ADSH planlaması yapılırken bu verilerin göz önünde bulundurulması, uygulanabilir bir programın oluşturulmasını destekleyecektir.

\section{Model Önerisine İlişkin Yaklaşım}

TÜİK engellilerin sorun ve beklentileri araştırması 2010 verilerine baktığımızda; sağlık hizmetlerinin iyileştirilmesi \%77 ile ikinci sırada (1. sırada \%85,7 ile sosyal yardım ve desteklerin artırılması) yer almaktadır. Sağlık hizmetlerinin iyileştirilmesi için öncelikle sağlı̆̆ı etkileyen unsurları belirlemek gerekir. Kişilerin sağlık hizmetlerini kullanmasında eğitim, bilinç, sağlık okuryazarlık düzeyi, sağlı hizmetlerine ulaşılabilirlik gibi unsurlar bulunmakla birlikte, özellikle engelli bireylerin sağlığını etkileyen çok sayıda faktör vardır. Bunları farklı bakış açılarına göre değişik şekillerde sınıflandırmak mümkündür.

Yapılan model önerisinde faktörler Şekil 1'de görüldüğü gibi; sağlık hizmetleri sunumu, fiziksel çevre, eğitim faaliyetleri, sosyal, kültürel, sanatsal ve sportif faaliyetler, ekonomik şartlar, Sivil Toplum Kuruluşları (STK), politik çevre ve uygulamalar ile yasal düzenlemeler olarak sınıflandırılmıştır. $\mathrm{Bu}$ sinıflandırmanın alt başlıkları ise Şekil 1a' da gösterilmektedir. Türkiye'deki tekerlekli sandalye kullanan ortopedik engelli bireylere ADSH sunumuna ilişkin uygulanabilir bir model önerisi oluşturmak için konunun sadece; ADSH sunumunun düzenlenmesiyle mümkün olamayacağı öngörülmektedir. Engelli bireyin sağlığını etkileyen tüm faktörleri kapsayan multidisipliner bir bakış açısıyla hazırlanacak olan modelin etkin ve sürdürülebilir bir yapıda olacağı görüşünden yola çıkılarak çalışma hazırlanmıştır. $\mathrm{Bu}$ yaklaşımla engelli bireyi etkilemesi muhtemel tüm unsurlarla ilgili yapılması önerilen uygulamalar 8 temel başlık altında sunulmaktadır.

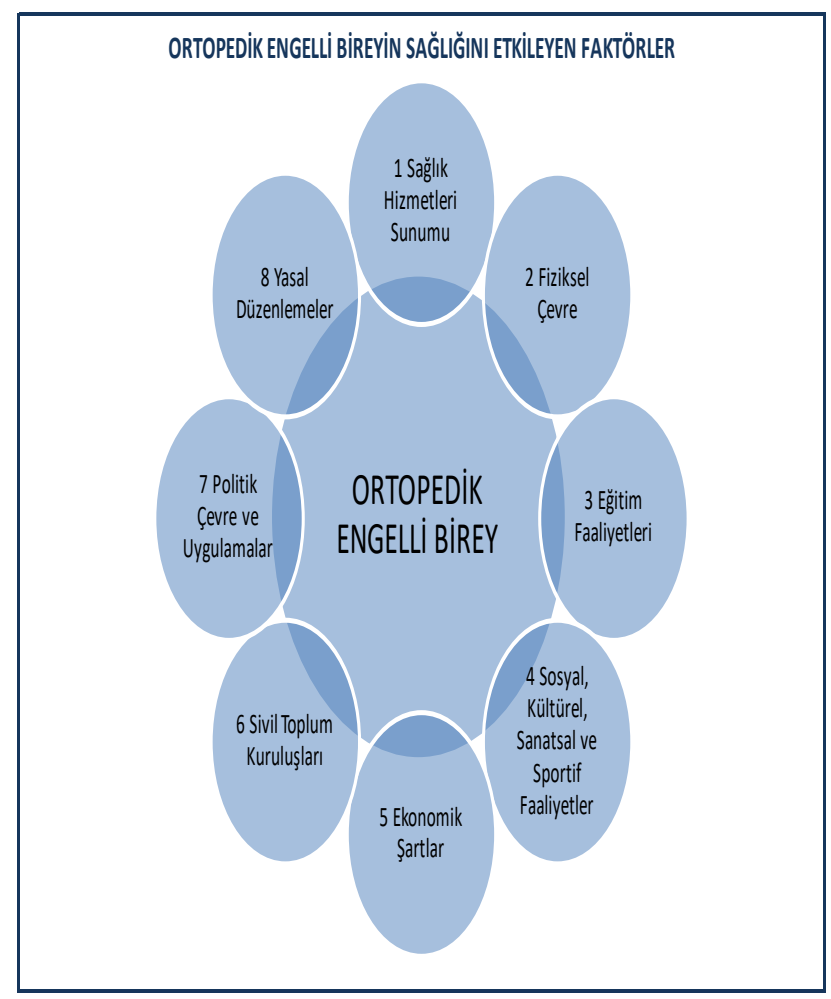

Şekil 1. Ortopedik Engelli Bireyin Sağlığını Etkileyen Faktörler 


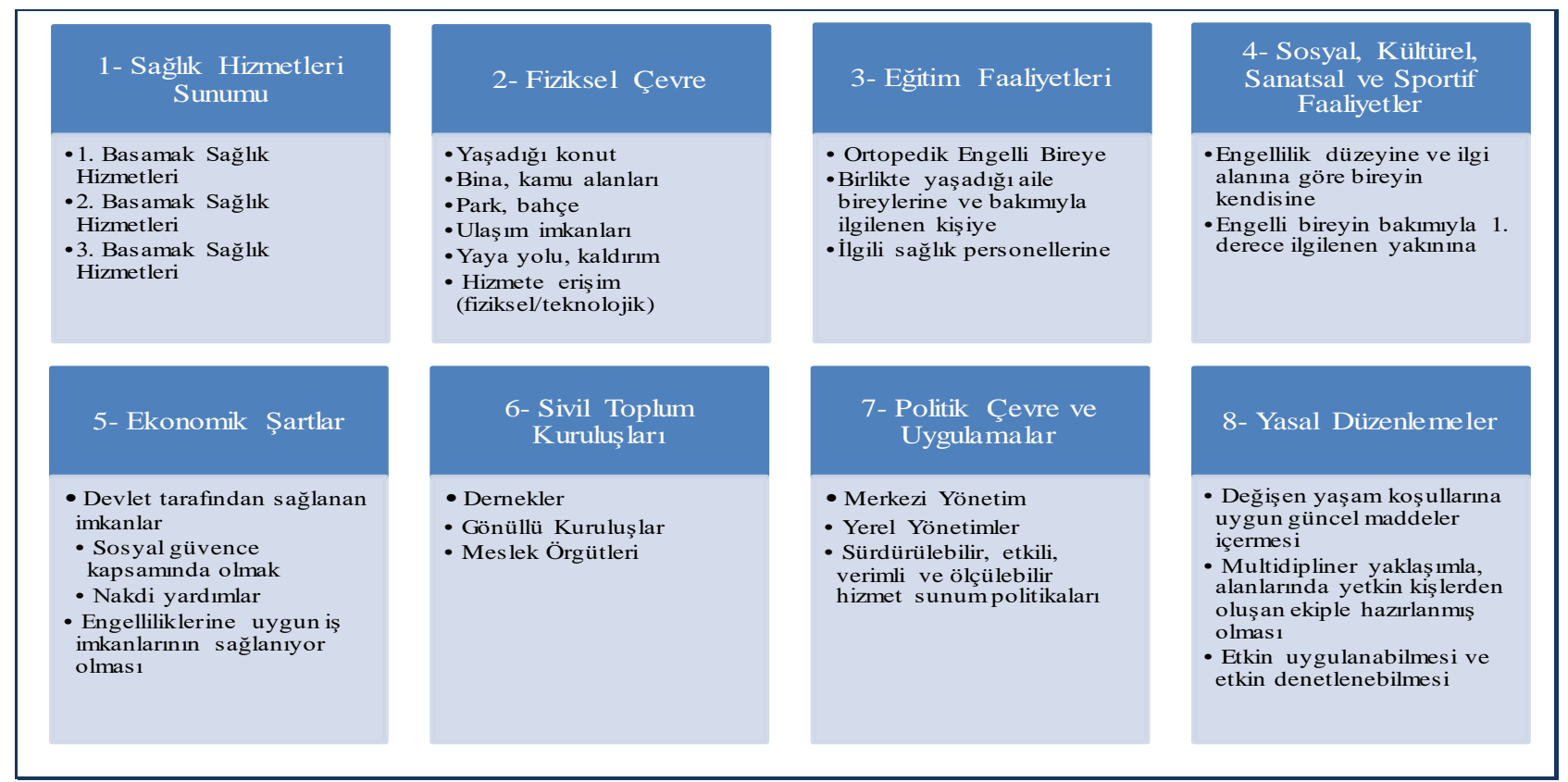

Şekil1a.Ortopedik Engelli Bireyin Sağlığını Etkileyen Faktörlerin Alt Başlıkları

Sağlık Hizmetleri Sunumuna İlişkin Öneriler Birinci basamak sağlık hizmetleri sunumu Sorunlar

1. Aile hekimliği hizmetlerinin, hekimlere düşen kişi sayısının yoğunluğundan dolayı etkin sunulamamasi.

2. ADSH'nin birinci basamak sağlık hizmetlerine entegre edilememesi.

3. Yetişmiş sağlık insan gücü kaynağının etkin ve verimli kullanılamaması.

\section{Çözüm Önerileri}

1. Sağlık bakanlığg 2019 verileri itibariyle toplam hekimlerin sadece \%16,32'si aile hekimlerinden oluşmaktadır. Sağlık sisteminin ve dolayısıyla sağlık verilerinin iyileştirilmesinde temel olan, aile hekimliğinin hekimler arasında tercih edilmesini sağlayacak şekilde; ücret politikası, aile hekimine düşen nüfusun azaltılması, kaynak desteğinin artırılması yoluyla çalışma şartlarının iyileştirilmesi gibi teşvik edici şartlarının oluşturulması.

2. Ağız ve diş sağlığında öncelikli olarak koruyucu ve önleyici hizmetlerin sunularak yüksek maliyetli olan tedavi edici hizmetlerin oranını düşürmek ve TDB Türkiye' de yıllara göre diş hekimi ve nüfus sayısı 2020 verilerine bakıldığında, diş hekimlerinin işsizlik oranının giderek arttığı görülmektedir. Değerli insan gücü kaynağı olan diş hekimlerine istihdam oluşturacak ve etkin değerlendirilmesini sağlayacak düzeyde her 4 Aile Sağlığı Merkezi (ASM) 2 diş hekimi ve yardımcısının görevlendirilmesinin sağlanması. Diş hekimlerinin ASM'lerde çalışma sistemine ilişkin önerinin ayrıntıları "Açıklamalar" başlığı altında yer almaktadır.

3. İşsizlik oranları artan yardımcı sağlık personellerine özel (hemşire, sağlık memuru vb.) ve benzer şekilde engelli bireylere hizmet sunacak diş hekimlerine özel de 1-3 ay süreyle verilecek "Engelli Bireylere Yönelik Sağllk Hizmetleri Sunumu Sertifika Programı'nın" düzenlenmesi sağlanabilir. Bu düzenleme ile engelli bireylere hizmet veren sağlık personeli uzmanlaşmış olacak ve atıl yetişmiş insan gücü değerlendirilerek, istihdam oluşturulacaktır. Yine her 4 ASM'ye engelli bireylerin ev ziyaretleri için sertifika programını tamamlamış olan 1 diş hekimi ve yardımcısının portatif ünit ve gerekli donanıma sahip gezici araçlarla hizmet sunumlarının sağlanması yoluyla da engelli bireylerin hizmete erişimleri sağlanarak, ASM ve ADSH veren diğer kamu kurumlarının yoğunluğu da azalmış olacaktır.

4. İşyeri hekimleri ile diş hekimlerinin aylık dönüşümlü çalışma planları oluşturularak, aynı zamanda sertifika programını başarıyla tamamlayan yardımcı sağlık personellerinin; cezaevleri, çocuk ıslah evleri, huzurevleri, 
korunmaya muhtaç çocukların barındı̆̆ı çocuk yuvaları ve yetiștirme yurtları gibi bir kısmında hekimin de olmadığı toplu yaşama alanlarındaki engelli bireylere hizmet sunmalarına da imkan sağlanmış olacaktır.

\section{Açıklamalar}

Sağlığın teşviki, koruyucu sağlık hizmetleri ile teşhis, tedavi ve rehabilitasyon hizmetlerinin bir arada verildiği, bireylerin hizmete kolayca ulaşabildikleri, düşük maliyetle etkin ve yaygın sağlık hizmeti sunumundaki birinci ve temel bileşen ASM'leridir. TÜİK sağlık personeli sayısının illere göre dağılımı 2018 verilerine baktığımızda ülkedeki toplam hekim sayısının 153128 olduğu ve bunların \%54,13'nün (82 894) uzman hekim, \%28,76'sinın (44 053) pratisyen hekim (geri kalan bölümün ise 26181 -\%17,09- asistan hekim) olduğu görülmektedir. Sağlık Bakanlığı'nın yayınladığı 2016 Sağlık İstatistikleri Yıllığı'na göre, bir aile hekimine düşen nüfus sayısı ise 3 267'dir. Sağlık bakanlığı verilerine göre ise ülkemizde 8000 ASM'de 25 000 hekim görev yapmaktadır. Belirtilen veriler dikkate alındığında ve koruyucu ve önleyici sağlık hizmetlerinin sağlık sisteminin gelişimi açısından oldukça önemli olduğu düşünüldüğünde bu alanda görev yapan hekimlerin sayısının çok yetersiz olduğu belirtilebilir. Sayıları az olan aile hekimlerinin muayenelerine ek olarak çeşitli idari görevleri de eklendiğinde iş yüklerinin oldukça fazla olduğunu söylemek mümkündür. Bu durumda da konumuz olan tekerlekli sandalye kullanan ortopedik engelli bireylerin muayeneleri, ev ziyaretleri, koruyucu ve önleyici uygulamaları için yeterli zaman ayıramayacakları düşünülmektedir. $\mathrm{Bu}$ açıdan özellikle engelli bireylerde ağız sağlığının zayıf olması kardiyovasküler hastalık ve akciğer enfeksiyonu gibi ciddi sistemik hastalıkların tetikleyicisi niteliğindedir. $\mathrm{Bu}$ sorunların ortaya çıkmasını engellemek için ağız ve diş sağlığına ilişkin sorunların önlenmesi ve erken teşhisi, bu sayede sağlık hizmetlerine ayrılan kaynakların etkili kullanımını sağlamak amacıyla düzenlemeler yapılması gerekmektedir (Buchholtz, 2012).
Düzenlemeler kapsamında; ASM'lerde diş hekimleri ve yardımcılarının görevlendirilmesi önerilmektedir. Böylelikle aile hekimlerinin iş yükleri de azalacak ve gelecek yıllarda daha da artması beklenen diş hekimi işsizlik oranını da düşürecektir. Her 4 ASM'ye 2 diş hekimi ve 2 yardımcı görevlendirmesi yapılarak, engelli bireylerin yanı sıra 65 yaş üstü bireyler, hamileler gibi dezavantajlı grupların ağız ve diş sağlığı hizmetlerine ulaşmaları da sağlanacaktır. Diş hekimleri ve yardımcılarının ASM çalışma planı olarak; 1 diş hekimi ve yardımcısı ayın 1 . haftası 1. ASM'de sonraki her bir haftada da kalan 3 ASM'de birer hafta olmak üzere muayene, tedavi ve bilgilendirme yapması sağlanacaktır. Engelli bireylere yönelik sağlık hizmetleri sunumu sertifika programını tamamlamış diğer diş hekimi ve yardımcısının da ev ziyaretlerinde görevlendirilmesi planlanmıştır. Bu ekip, portatif ünit ve diğer mobil ekipmanların olduğu gezici araç ve şoför temin edilerek, görevli olduğu 4 ASM'de kayıtlı olan engelli bireylerin ev ziyaretleri ile muayene ve tedavilerini yapmak üzere görevlendirileceklerdir. 4 ASM'de görev yapan 2 diş hekimi ve 2 yardımcı planladıkları şekilde ayın son 2-3 günü ise birinci basamakta ADSH'nin geliştirilmesine yönelik toplantılarla çalışmalarının değerlendirmelerini yapmış olacaklardır. Böylelikle aynı hastaları takip eden sağlık personelleri ve aynı sağlık personelinden hizmet alan hastalar için karşılıklı güvene dayalı daha etkin sonuçların alınabileceği bir hizmet sunulmuş olacaktır.

Ev ziyaretlerinin bir kısmı da 3-6 aylık periyotlarda planlı șekilde, birlikte çalıșılan aile hekimiyle gerçekleştirilmesi ise modelin diğer bir parçasıdır. Aile hekimiyle gerçekleştirilen ev ziyaretlerinde amaç sadece fiziki muayene değil; engelli bireye, engelli bireyin bakımından birinci derecede sorumlu bireye ve aile fertlerine eğitim verilerek engellilik durumuyla ilgili bilinç düzeylerinin artırılması ve engelli bireyin yaşadığı ortamın bütüncül olarak değerlendirilmesidir. Bütüncül değerlendirmede; engelli bireyin yaşadığı evin ve çevresinin fiziksel şartlarının engelli kullanımına uygun olup olmadığının, engelli bireyin sadece fiziksel 
değil aynı zamanda psikolojik durumunun, ayrıca aile fertlerinin de engelli bireye bakmanın getirdiği zorluklar nedeniyle psikolojilerinin değerlendirilmesini kapsayan bir yaklaşımdır. Ekip halinde yapılan ev ziyaretleri sonrasında yapılan değerlendirmelerde tespit edilen ihtiyaçlara yönelik faaliyetlerin TSM ve belediyelerin evde sağlık hizmetleri birimiyle temasa geçilerek organize edilmesi sağlanır. İhtiyaca göre belirli periyotlarda engelli birey ya da aile bireyleriyle online psikolog ve/veya psikiyatrist görüşmelerinin ya da ilgili branş hekimiyle online görüşme yapılmasının sağlanması da planlanan düzenlemeler arasında yer almaktadır.

\section{Íkinci Ve Üçüncü Basamak Sağlık Hizmetleri Sunumu Sorunlar}

1. Etkin bir sevk zincirinin bulunmaması 2. - 3 . Basamak sağlık hizmetlerinde önlenebilir yoğunluğa neden olmakta ve kaynakların verimli kullanılamamasına yol açmaktadır.

2. Engelli bireyin muayenesi, tetkiklerinin yapılması sonuçlarının alınması, ilgili hekime gösterilmesi ve gerekiyorsa ilaç yazllarak, temin edilmesinde teknolojik imkanlardan yeterince yararlanılmamaktadır.

\section{Cözüm Önerileri}

1. Engelli bireylerin öncelikli olarak aile hekimlerini tercih etmelerini sağlayacak bilgilendirici eğitimler verilmesi, erişimlerinin kolaylaştırılmasını sağlayacak araç tahsisi ve/veya fiziksel çevre düzenlemelerinin yapılması sağlanmalıdır. Ayrıca aile hekimi sayılarını arttırarak yoğunluğun azaltılması yoluyla 1. Basamak sağlık hizmetine erişimi kolaylaştırarak, 2. ve 3. Basamak hizmetlerin öncelikli tercih olmaktan çıkartılması sağlanmalıdır.

2. Evde muayene edilen engelli bireye tetkik yapılması gereken durumlarda, eve gelen sağlık personeli tarafından alınan numune ASM, Toplum Sağlığı Merkezi (TSM) ve evde bakım hizmetleri koordinasyonu ile laboratuvara gönderilir. Ancak mevcut uygulamada sağllk sistemleri akut bakıma göre planlanmıștır. Özellikle birinci basamak bakım hizmetleri özel bakım, tıbbi donanım ve reçeteler için bir bariyer oluşturmaktadır. Bu bariyer kesinlikle gerekli olmakla birlikte bazı durumlarda engellilerin sağlı hizmetine erişiminde problem oluşturabilmektedir. Reçete ve sevklerin belirlenmiş durumlar için, doktorla yüz yüze görüşmeden gerçekleştirilmesini sağlayacak kılavuzlar oluşturulması sağlanmış olmalıdır (İnan ve ark., 2013). Bu nedenle, sonuç almak için engelli birey yakının ilgili sağlık kurumuna gitmesi, sıra bekleyerek sonuç göstermesi ve ilaç yazılması gereken durumlarda da hekimden reçete kodunu alması yerine numune sonucu ilgili hekime otomasyon sistemi üzerinden ileterek, gerekli yönlendirme (ilaç, uygulanması gerekenlere ilişkin bilgi vb.) ilgili aile hekimine yine otomasyon üzerinden iletilebilir. Yüz yüze görüşülmesine gerek olmayan durumlar için de engelli bireye ya da yakınına mesajla bilgilendirme yapılabilir. Böylelikle engelli birey yakının ciddi bir zaman ve emek harcayarak yapacağı işlemler hastaneye gidilmesine gerek kalmadan teknolojik imkanlarla kolaylıkla çözülmüş olacak ve hastanelerdeki gereksiz yoğunlukta azaltılmış olacaktır.

3. Özel ADSM ve özel hastanelerle yapılacak anlaşmalarla tüm özel sağlık kurumlarının hizmet sunduğu bölgedeki engelli bireylerle, ilgili aile hekiminin yönlendirmesi ve yasal olarak sınırlandırılmış şekilde (tüm branş hekimlerince yılda 2 kez vb.) diş hekimleri ve ihtiyaç duyulan ilgili uzman hekim tarafından hastanede veya hastalığın durumuna uygunsa evinde muayene ve/veya tedavi edilmesi sağlanabilir. $\mathrm{Bu}$ uygulama sayesinde hizmet sunumu özel ve kamu sağllk kurumlarınca paylaştırılır, kamu hastanelerinin yükü azaltılarak, kaynakların etkin kullanımıyla hizmet kalitesinin artması ve engelleri bireylerin sağlı hizmetlerine erişimi sağlanmış olur.

4. Sigorta kapsamında yer alan engelli bireyin, aile hekiminin yönlendirmesiyle, özelden ya da kamudan alması planlanan hizmetlerde haklı gerekçe belirtmeden yılda en fazla $2 \mathrm{kez}$ gitmemesi durumunda sigorta kapsamından çıkartılması gibi şartlarla engelli birey ve ailesini de hizmet alımından sorumlu tutmak, sistemin daha sorunsuz işlemesi açısından önemli bir uygulamadir. 


\section{Fiziksel Çevre Şartlarına İlişkin Öneriler} Sorunlar

1. Fiziksel düzenlemelerin yaşam alanlarında yeterli düzeyde olmaması, engelli bireylerin topluma adapte olmaları ve sağlık, eğitim, sosyal faaliyetler gibi haklarına ulaşmalarında ciddi sorunlara neden olmaktadır.

2. Fiziki şartlara ilişkin maddelerin yasalarda yeterli düzeyde yer almaması, olanların ise pratikte yeterince uygulanamaması önemli sorunlar arasında yer almaktadır.

3. Engelli bireylerin diş muayeneleri için özel apart desteğinin yetersizliği.

\section{Çözüm Önerileri}

1. Engelli bireyin yaşadığı evin ve binanın fiziki şartlarının engelli bireye uygunluğu, ilgili belediyenin evde bakım hizmetleri kapsamında değerlendirilerek, belediye ile meslek grupları arasında önceden yapılmış anlaşmalar gereği yönlendirme ve koordinasyon sağlanarak, gerekli düzenlemelerin yapılması ciddi gereksinimleri karşılayacaktır.

2. Yol, kaldırım, yaya yolu, park, bahçelerin, sinema tiyatro, alışveriş merkezi ya da kamu binalarının fiziksel şartlarının engelli bireylerin erişimine imkan tanıyacak yasal düzenlemelere uygun olmaması halinde açılışına izin vermemek ve/veya hizmette olan alanların ise gerekli düzenlemeleri yapmaları için süre verilmek suretiyle şartları yerine getirmeleri sağlanmalıdır.

3. Tekerlekli sandalye kullanan ortopedik engelli bireylerin diş hekimi koltuğuna oturmalarını sağlamak da diğer bir fiziksel sorun olarak karşımıza çıkmaktadır. Bu amaçla tasarlanan tekerlekli sandalye kullanan engelli bireyin muayenesi ve tedavisi için sandalyesinden kalkmadan, sandalyeye pozisyon verilmesini sağlayan özel bir sistem ve benzer şekilde tekerlekli sandalye kullanan engelli bireyler için tasarlanmış muayene koltuğu da ülkemizde mevcuttur. Ancak uygulamada kamu kurumlarının hepsinde ve yeterli sayıda bulunmamaktadır. Bu özel sistemlerin ihtiyaç alanlarının ve sayılarının optimum düzeyde tespit edilmesi ve ilgili alanlarda temin edilmesine yönelik çalışmada planlanmaktadır.
4. Fiziksel engelli bireylerin ve ailelerinin mobil hizmetleri tercih etmelerini sağlayacak teknolojik imkanlar için destek olunmasına yönelik düzenlemeler yapılmalıdır. $\mathrm{Bu}$ kapsamda; engelli bireylere internet desteğinin uygun şartlarda ve geniş kapsamlı verilmesini sağlayarak, online alışveriș, online sağlık görüşmeleri gibi mümkün olan hizmetlere kolay ulaşımları sağlanmalıdır.

5. Toplu taşıma araçlarının ve/veya bu araçlara ulaşım güzergahlarının bir kısmında yasal olarak zorunlu olmasına rağmen, engellilere yönelik düzenlemeler yeterli düzeyde bulunmamaktadır. Gerekli koşulları sağlamayan araçların, şartları karşılayana kadar trafikten çekilmesi, konuyla ilgili denetimlerin yapılarak, uygulamanın taviz verilmeden yerine getirilmesi sağlanmalıdır. Ayrıca ortopedik engelli bireylere yönelik gerekli çevre düzenlemelerine ilişkin en iyi örnek uygulamaları yapan belediyelerin ödüllendirilmesi; yapmayan belediyelere de merkezi yönetim tarafından yaptırım uygulanması sağlanmalıdır.

6. Konuyla ilgili denetimlerin hassasiyetle yapılmasına yönelik ilgili denetim ekiplerine engellilere yönelik farkındalık eğitimlerinin verilmesi sağlanmalıdır.

\section{Eğitim Faaliyetlerine İlişkin Öneriler Sorunlar}

1.Engelli bireylerin fiziki şartların yetersizliğinden dolayı eğitim hizmetlerine yeterli düzeyde erişememeleri.

2.Engelli bireylerle ilgili, toplumun genelinde farkındalık düzeyinin oldukça düşük olması.

3. Sağlık insan gücü eğitimdeki nitelik, yeterlilik ve kalite standardizasyonunun eksik olması.

4.Engelli bireylere hizmet sunan sağlık personelinin eğitimlerinde farkındalığın oluşmasına yönelik yeterli uygulamanın bulunmaması.

\section{Çözüm Önerileri}

1.Fiziksel çevre şartlarında yapılacak düzenlemeler sayesinde engelli bireylerin toplumsal yaşama entegre olmasını sağlayacak temel insani hakları arasında yer alan eğitim alma haklarına ulaşmaları sağlanmış olacaktır.

2.Eğitim sisteminde, özellikle içinde bulunduğumuz covid-19 pandemi süreci 
nedeniyle de kullanılmaya başlayan online eğitim sistemine ortopedik engelli bireyleri de dahil ederek, onlara özel uygulamalarla online eğitim süreci kapsamının geliştirilmesi sağlanmalıdır.

3.Engelli bireyin aile fertlerinin engelli bireye yaklaşımlarıyla beraber, engelli bireyle birlikte yaşamanın getirdiği zorluklarla başa çlkabilmeleri konusunda bilinçlenmelerine yönelik, ASM, TSM ve belediyelerin işbirlikleri ile eğitimler verilmesi sağlanmalıdır.

4.Engelli bireylere hizmet sunulan sağllk personelleri tarafından kimi zaman engellilerden, minnettar tavir beklentisi gibi psikolojik yönden olumsuz hissettirecek davranışlar sergilenmesi gibi tutumların engellenmesi amacıyla etkin farkındalık eğitimleri verilmesi sağlanmalıdır.

5.İnsanların engellilere karşı olan önyargı ve tutumlarından dolayı, engellilerin toplumsal yaşama katılmakta zorlandıkları bilinmektedir. $\mathrm{Bu}$ tutum ve davranışları eğitimle değiștirmek mümkündür (Tekin ve Madan, 2015). Engelli olmayan veya yakın çevresinde engelli birey bulunmayan kişilerin engelli bireylerle ilgili farkındalığının ve hassasiyetinin arttırılması amaciyla düzenlenecek kampanyalar oldukça önemlidir. Kampanyalarla ilgili yapılan bir araştırmada; ağız ve diş sağlığı muayenelerini, koruyucu ağız ve diş sağlığı uygulamalarını kapsayan ve farkındalık oluşturmak amacıyla yapılan 35 ağız sağlığı kampanyası incelenmiştir. Çalışma sonucunda, sosyal pazarlama uzmanlarının desteği ile düzenlenen kampanyaların daha etkili olduğu ve kampanyaların genel olarak önleyici ağız sağlığı uygulamaları ile özellikle çocuklarda sürdürülebilir ve uzun dönemde ağız sağlı̆̆ını geliştirici sonuçlar verdiği ve böylelikle diş tedavi maliyetlerini düşürebileceği bilgisine ulaşılmıştır (Mumcu ve ark., 2013). Bu çalışma ve literatürdeki benzer çalışma sonuçları değerlendirildiğinde, yerel yönetimler ve sosyal kurumlar aracılığı ile toplumu aydınlatacak eğitici oral sağlık programları düzenlenmesi gibi uygulamaların yapılması, etkinliğin değerlendirilmesi ve kayıtlarının düzenli tutuluyor olması sonrasında düzenlenecek faaliyetler içinde yön verici olacaktır (Sancaklı, 2009).

\section{Sosyal, Kültürel, Sanatsal ve Sportif Faaliyetlere Ilişsin Öneriler Sorunlar}

1.Tüm engelli bireyleri ve bakımından birinci derecede sorumlu olan fertleri kapsayacak nitelikte, yeterli sosyal, kültürel, sanatsal ve sportif faaliyetlerin sistematik organize edilmiyor olması.

2.Bu faaliyetlere online - mobil ulaşım olanaklarının etkin kullanılmaması.

\section{Çözüm Önerileri}

1. Belediye, TSM, dernek ve gönüllü kuruluşların iş birliği ile engelli bireyin ilgi alanına yönelik faaliyetlerin belirli periyotlarda düzenlenmesi ve yüksek katılımın sağlanması için ihtiyacı olan engelli bireylere araç tahsis edilmesi, faaliyete uygun alan ayarlanması, faaliyete özel malzeme ve ekipman temin edilerek, faaliyetlerin organize edilmesi sağlanmalıdır.

2. Tiyatro ve sinema salonlarının tekerlekli sandalye kullanan ortopedik engelli bireylerin ulaşımına uygun tasarlanması, ayrıca gösterimde olan film ve tiyatrolara ulaşımda engellilere özel online izleme imkanlarının sunulması sağlanabilir.

3. Engelli bireyin bakımıyla birinci derece sorumlu olan kişilerin psikolojik açıdan desteklenmelerine katkı sağlamak amacıyla; ilgi alanlarma uygun faaliyetler düzenlenmesi ve düzenlenen faaliyet gününde engelli bakımından sorumlu kişilerin, bakımından sorumlu olduğu engelli bireylerle ilgilenilmesini sağlayacak ekipler oluşturularak katılımının organize edilmesi sağlanabilir.

\section{Ekonomik Şartlar Sorunlar}

1. ADSH'nin büyük oranda cepten ödemelerle karşılanıyor ve ülke koşullarına göre bu hizmetlerin oldukça yüksek fiyatlarda sunuluyor olması.

2. Sosyal güvence kapsaminda bulunmayan engelli oranının \%52,5 olması. Engelli bireylerin \%85,7'si (TÜİK., 2010) çalışmıyor olması ve bu nedenle ekonomik zorluk yaşıyor olmalarından 
dolayı oldukça pahalı olan ADSH'ne erişimde ciddi zorluklar yaşamaları.

\section{Çözüm Önerileri}

1. Cepten ödemelerin ağırlıklı olduğu ve dişa bağımlı malzeme alımından dolayı yüksek maliyetlere sahip olunan ADSH'nin sunumu da bu nedenle oldukça yüksektir. Hizmet alımında genel olarak gecikme eğiliminde olan hastalar, aynı zamanda ülkede yaşanan sosyo-ekonomik koşullardaki dalgalanmalardan bu alana kaynak ayırma konusunda önemli ölçüde etkilenmektedirler (Glick ve ark., 2012). Sağlığın korunması ve kıt ekonomik kaynakların verimli kullanımı için de önceliği tedavi edici değil; koruyucu ve önleyici hizmetlere ayırmak gerekmektedir. Bu yaklaşımla düzenli ve etkin diş fırçalama sayesinde başta ağız ve diş sağlığı sorunları olmak üzere, sağlıksız ağız ve dişlerden kaynaklı oluşabilecek birçok hastalık ve beraberinde getirdiği tedavi masraflar da önlenmiş olacaktır. Bunu sağlamak amacıyla; okul öncesi eğitimden başlayan süreç, birinci basamağa entegre edilen ADSH'leri ile sürdürülmeli ve kampanyalarla desteklenmelidir.

2. Katkı payları ile sigorta kapsamında randevu sistemi ile hizmet sunulan ağız ve diş sağlığ hastaneleri sistemi önemli ölçüde rahatlatmakla beraber bu hastanelerde de ciddi yoğunluk görülmektedir. Sevk zincirinin etkin kullanımının sağlanması ve özel ADSM'leri ile yapılacak anlaşmalar, hastanelerdeki yoğunluğu azaltacak, diş hekimleri tarafından hastalara ayrılan zaman artacak, muayene aralarında gerekli düzenlemeleri yapmak için sağlık personelinin ihtiyaç duyduğu zaman sağlanmış olacak, böylelikle daha kaliteli hizmet sunumu sağlanacaktır.

3. Sigorta kapsamında olmayan ortopedik engelli bireylerin, engellilik durumlarına uygun gerektiğinde evden çalışmalarını sağlayacak iş olanakları ile ekonomik kazançlarının arttırılması, üretime sağladıkları katkıdan dolayı güven duygularının artması ve nihai olarak da üreterek sigorta kapsamında olmaları sağlanmış olacaktır. $\mathrm{Bu}$ amaçla, engellilerin meslek seçebilmesi ve bu alanda eğitim alabilmesi için gerekli tedbirler alınmalıdır. Çalışma ve Sosyal
Güvenlik Bakanlığınca yapılan meslek analizleri doğrultusunda engelliler için Millî Eğitim Bakanlığı ve Çalışma ve Sosyal Güvenlik Bakanlığınca mesleki habilitasyon, rehabilitasyon ve eğitim programları geliştirilir. Ancak mevzuatta yer alan ifadelerin uygulanmasinda sorunlar yaşanmaktadır. (T.C. Resmi Gazete, 07 Temmuz 2005, Sayı: 25868.) Bu nedenle mevzuata net olarak; firmalara engelli çalıștırma zorunluluğunun etkin kullanılıyor olmasıyla beraber, evden engelli çalıştırma maddesinin de eklenmesi sağlanmalıdır.

\section{Sivil Toplum Kuruluşları Sorunlar}

1.Dernekler, gönüllü kuruluşlar, meslek örgütleri gibi toplulukların engelli bireylere ilişkin farkındalık seviyesinin düşük olması ve mevzuatta konuyla ilgili bir yaklaşımın bulunmaması.

\section{Çözüm Önerileri}

1.Dernekler, gönüllü kuruluşlar, meslek örgütleri gibi toplulukların özelliklerine uygun olarak engellilerle ilgili görevlendirmelerinin yasal açılış şartlarına eklenmesi sağlanabilir.

2.Evde ziyaret edilen engelli bireyle ilgili tespit edilen bir ihtiyacın ilgili meslek kuruluşuna iletilmesiyle o meslek grubunda ilgili bireyin yaşadığı bölgede hizmet sunan meslek sahibinin sınırlandırılmış belli bir bütçeye kadar (yılsonu vergilendirilmiş toplam geliri üzerinden belli bir yüzde belirlenmesi gibi) olan hizmeti engelli bireylerin ihtiyacı doğrultusunda sunması sağlanabilir. Örneğin; engelli bireyin ev ziyareti sırasında tespit edilen, banyosunun tekerlekli sandalye kullanan ortopedik engelli bireyin kullanımına uygun olmadığı ve/veya duvarlarının bazı bölümlerine tutamak yapılması gerektiği tespit edildiğinde, ilgili bölgede kayıtlı olarak hizmet sunan meslek sahibine yönlendirme yapılarak gerekli tadilatın yapılması, belirlenen belli bir bütçeye kadar gerektiğinde kamu bütçesinden de ilave yapılarak sağlanmalıdır. Meslek sahibini teşvik edici olması açısından da engeli bireylere sunulduğu hizmet bedelinin kanıtlanabilir belgesi/leri ile (makbuz, düzenlemenin öncesi ve sonrası fotoğraflar vb.) kamu kuruluşlarından mesleğiyle ilgili iş yönlendirmesi yapılması sağlanabilir. 
Politik Çevre ve Uygulamalara İlişkin Öneriler Sorunlar

1. Merkezi ve yerel yönetimlerin birbiriyle yeteri düzeyde entegre çalışmaması.

2.Merkezi ve yerel yönetimler tarafından tutulan kayıtların düzenli - sistematik olmaması ve resmi kayıtlarda birbiriyle örtüşmeyen verilerin bulunması.

3.Kısa, orta ve uzun vadeli ulusal ve bölgesel düzeyde kapsayıcılığı olan, sürdürülebilir, denetlenebilir, etkin, verimli ve ölçülebilir stratejik hedeflerin yeterince belirlenmemesi, belirlenen hedeflerin ise; merkezi ve yerel yönetimlerde ilgili dönemdeki yöneticiye bağlı politikaların uygulanması, yönetici değiştiğinde uygulamaların yürürlükten kalkması, durması ya da kesintiye uğraması.

4.Belediyeler tarafından sunulan evde bakım hizmetlerinin ve kaynaklarının yetersizliği.

5.Cezaevleri, çocuk sslah evleri, huzurevleri, korunmaya muhtaç çocukların barındığı çocuk yuvaları ve yetiştirme yurtları gibi bir kısmında hekimin olmadığı toplu yaşama alanlarındaki engelli bireylerin ADSH'ni almalarını sağlayacak yeterli organizasyonun bulunmaması ve mevzuatla desteklenmeyen uygulama güçlügü.

\section{Çözüm Önerileri}

1. Merkezi idarenin, yerel nitelikli hizmetlerin yürütülmesindeki önemli destekleyicilerinden birisi de belediyelerdir. Özellikle 2000'li yıllardan itibaren yerel yönetim alanında yapılan reformlarla engellilere yönelik yerel nitelikli hizmetlerde belediyelere bazı yetki ve görevler verilmiştir. Böylece engellilere sunulan yerel hizmet ve politika konusunda merkezi yönetimin yanında belediyeler de temel aktör olarak yerini almaya başlamıștır. Reform döneminde 5216 sayılı Büyükșehir Belediye Yasası, 5393 sayılı Belediye Yasası ile 2012 yılında çıkarılan 6360 sayılı yasa engellilerle ilgili belediyelere yönelik görevler yüklenmiştir (Kalaycı ve Akın, 2019). Bu uygulamalar gerçekleştirilmesi planlanan faaliyetlerin daha dinamik bir yapıda sunulmasını sağlarken; merkezi ve yerel yönetimlerin iş birliği içinde olmamaları, kaynakların etkin ve verimli kullanımın düzeyini düşürebilmektedir. $\mathrm{Bu}$ sorunları önlemek aracılığıyla düzenli bilgi paylaşımı ve iletişim sağlanmalıdır.

2. Devletin resmi kurumlarının aynı konu başlıklarına ilişkin farklı verileri bulunmaktadır. $\mathrm{Bu}$ durum kayıtlara olan güvensizliğe neden olmakla beraber, kaynakların hakkaniyetli dağıtılmasına ve hazırlanan politikalarla ilgili yanlış kararlar verilmesine neden olabilmektedir. $\mathrm{Bu}$ nedenle bilimsel metotla kaydedilen verilere ihtiyaç vardır. Bilimsel kabul edilebilirlik; bir tedbirin güvenilirliğini ve geçerliliğini içerir (DQA., 2019). Temel toplam kalite yönetimi ilkelerinden olan; ölçemediğinizi yönetemezsiniz yaklaşımıyla, öncelikli olarak kayıtların doğru, güvenilir ve düzenli tutulmasını sağlayacak bir sistem ve dinamik bir kontrol mekanizması oluşturulmalıdır.

3. Ülkemizde cumhuriyetin kurulmasından sonra ülke refahının yükseltilmesi adına sağlık da dahil olmak üzere bütün kamu hizmetlerinde yatırımlar yapılmaya başlanmıştır. Ancak sağlık alanında siyasî kaynaklı sorunlardan dolayı istikrar sağlanamamıștır (Karagöz ve ark., 2019). Sağlığa yansıyan bu siyasi istikrarsızlığın giderilebilmesi için, kişiye bağlı olmayan sistematik, kısa, orta ve uzun vadeli ulusal ve bölgesel gerçekliklere uygun ve kapsayıcılığ olan, sürdürülebilir, denetlenebilir, etkin, verimli ve ölçülebilir stratejik hedeflerin belirlenmesi gerekmektedir. Bu amaçla, sağlıklı davranışların ve etkili halk sağlığ uygulamalarının teşvik edilmesi, ağız sağlığını kontrol altına almak için ulusal liderlik sağlaması önemlidir (OHP Strategic plan, 2011). Belirlenen hedefler ve ulaşılmasına yönelik stratejiler yerel yönetimlerle uygulanabilirlik ve ulaşılabilirlik açısından değerlendirilmeli. Fikir biriliği ile son haline gelen hedefler merkezi yönetimlerce takip edilmeli, iyi uygulamalar ödüllendirilmeli, ulaşılamayan hedefler sorgulanmalı ve şüpheye yer vermeyecek, kanıtlanabilir haklı gerekçeler gösterilerek, yaptırımlar (ödenekten kesinti, kadro değişimi vb.) uygulanmalıdır. Her bölgedeki engelli bireylerin detaylı listesi oluşturularak, aylık-yıllık ve 5 yıllık hedeflerin belirlenmesi, takibinin yapılarak, düzenli kaydedilmesi sağlanmalıdır. Aylık hedefler; işe başlayan engelli sayısı, sosyal faaliyete katılan engelli sayısı, 
yıllık hedefler; genel ve ağız-diş muayenesi yapılmış ve eğitim verilmiş engelli sayısı, fiziki alanlarında düzenleme yapılmış engelli sayısı. 5 yllık hedef; ek hastalıklarında iyileşme kaydeden engelli sayısı, psikolojik destek almasına ihtiyaç kalmayan engelli sayısı gibi ölçülebilir, denetlenebilir ve gerçekçi olmalıdır.

4. Evde bakım hizmetleri sayesinde, engelli bireyin ve ailesinin yaşam koşullarının iyileştirilmesi ile sağlık sorunlarının karmaşık hale gelmeden çözülmesi sağlanarak, hastanelerde meydana gelebilecek yı ğılmaların önlenmesi, hastanede yatış sürelerinin azaltılması, bu suretle tedavi maliyetlerinin düşürülmesini de sağlanmış olacaktır. $\mathrm{Bu}$ amaçla evde bakım hizmetleri ekiplerinin ve kaynaklarının artırılması için toplam sağlık kaynaklarının tekrar gözden geçirilmesiyle, bu alana ayrılan miktarının artırılması, kullanımının gözden geçirilmesi ve gerekli alanlarda revize edilmesi sağlanmalıdır.

5. Cezaevleri, çocuk ıslah evleri, huzurevleri, korunmaya muhtaç çocukların barındığı çocuk yuvaları ve yetiştirme yurtları gibi alanlarla ilgili olarak birinci basamak hizmetlere ilişkin 25.01.2013'te yayınlanan “aile hekimliği uygulama yönetmeliğinde" madde 6 'da belirtilen düzenlemeler bulunmaktadır. Ancak belirtilen hususlar engellilere yönelik olmayıp, yaşam koşullarının zor olduğu bu alanlardaki tüm bireyleri kapsamaktadır. Özellikle belirtilen alanlarda yaşayan engelli bireyleri kapsayan daha detaylı bir mevzuat hazırlanması sağlanmalıdır.

\section{Yasal Düzenlemelere İlişkin Öneriler Sorun}

1.Fiziksel engelli bireylere yönelik yeterli yasal düzenlemelerin bulunmaması ve olanların ise yeterli ve etkin uygulanamaması.

\section{Çözüm Öneri}

1.Engellilere ilişkin tüm yaşantılarını kapsayıcı nitelikte yasal düzenlemelerin oluşturulması ve var olanların gözden geçirilmesi sağlanmalıdır. Mevzuat oluşturulurken; hukukçular, sağlıkçılar, engelli bireyler ve engellileri temsilen ilgili dernek ve gönüllü kuruluşlar, planlanan mevzuatın içeriğine göre ilgili sektör temsilcileri gibi tüm paydaşların katılımının sağlanmasıyla, uygulanabilir bir yapının tasarlanmasına yönelik çalışmalar yapılmalıdır.

\section{GEREÇ ve YÖNTEM}

Cenevre'de 1984 yılında Dünya Sağlık Örgütü tarafından kullanılan ve 20 yılı aşkın süredir DSÖ ve üye devletleri için sağlık stratejisine yönelik önemli bir odak noktası görevi gören "Herkes için sağllk" ifadesi evrensel insan haklarının vazgeçilmezidir. Herkes için sağlı ifadesinden yola çıkılarak, toplumda dezavantajlı gruplar arasında yer alan tekerlekli sandalye kullanan ortopedik engelli bireylere yönelik yapılan bu çalışmada, konuyla ilgili ulusal ve uluslararası yayınlanmış makaleler, Türkiye'de engellilere yönelik düzenlenen anket sonuçları, araştırma raporları, yasa ve yönetmeliklerdeki engellilerle ilgili maddeler, gönüllü kuruluşlar ve dernek çalışmaları ile mevcutta uygulanan sağlık hizmetlerine ilişkin bilgilerin yer aldığı literatür incelenmiş, biri kamu diğeri özel sağlık kuruluşunda çalışan iki diş hekimi ile görüşme yapılmıştır. Ayrıca TDB tarafından yayınlanan istatistik verileri ile Türk Diş Hekimlerine yönelik mevzuat incelenmiştir. Yapılan araştırmalardan elde edilen bilgilerin yorumlanması sonucunda da “Türkiye'de

tekerlekli sandalye kullanan ortopedik engelli bireylere ADSH sunumuna ilişkin model önerisi" oluşturulmuştur. Yapılan tüm bilimsel araştırma ve çalışmalarda sürekli gelişim esas olduğundan, sunulan model önerisi de; yapılacak ayrıntılı çalışmalarla hizmet sunumunda kaynakların daha etkin kullanımına ve hakkaniyetli olmasına imkan sağlayacak düzeyde geliştirilebilir niteliktedir.

\section{BULGULAR}

Sağlık Bakanlığı tarafından uygulanan birçok program ve düzenlemelerle, temel halk sağlığı sorunlarına yönelik olarak tüm vatandaşları tek çatı altında toplayan genel sağlık sigortası, yaygın, erişimi kolay ve güçlendirilmiş temel sağlık hizmetleriyle, evde bakım hizmetleri kapsamındaki uygulamalarla tüm vatandaşlar için olduğu gibi ortopedik engelliler açısından da sağlık hizmetleri alanında önemli gelişmeler sağlanmıştır. Ancak uygulamaya baktığımızda 
tekerlekli sandalye kullanan ortopedik engelli bireylerin ADSH'ne erișimleri konusunda devam eden ciddi sorunlar olduğu görülmektedir.

Tekerlekli sandalye kullanan ortopedik engelli bireylerin ADSH'ne erişimlerinde karşılaştıkları sorunların çözümlenebilmesinin sadece bu alana yönelik düzenlemelerle yeterli, kalıcı ve sürdürebilir olamayacağı görüşünden yola çlkılarak tasarlanan multidispliner model önerisi ile Şekil 1'de ve 1a'da görüleceği gibi 8 temel başlık altında ele alınmıştır. Her başlık altında yer alan toplam 33 maddeden oluşan çözüm önerilerinin detayları çalışmada sunulmaktadır.

Önerilere genel olarak bakıldığında; Türkiye' deki engelli bireylerin sorun yaşadıkları en önemli alanların başında sağlık hizmetlerine erişim gelmektedir. $\mathrm{Bu}$ alanla ilgili olarak öncelikle, birinci basamakta yer alan ve sağlık hizmetlerinin temelini oluşturan koruyucu ve önleyici sağlık hizmetleri sunumunu sağlayan aile hekimliği sisteminin iyileștirilmesine yönelik çözüm önerileri sunulmaktadır. Ayrıca ADSH'nin birinci basamak sağlı hizmetlerine entegre edilmesini ve işsizlik oranı artan diş hekimlerine istihdam sağlamak amacıyla diş hekimlerinin ASM'lerde asistanlariyla görev almaları üzerine bir çalışma planı oluşturulmuştur. Benzer şekilde atama bekleyen ve atıl durumda olan yardımcı sağlık personellerine yeni bir iş olanağı oluşturulmak üzere 3 aylık "Engelli Bireylere Yönelik Sağlık Hizmetleri Sunumu Sertifika Programı" nın düzenlenmesi engelli bireylerin sağlık hizmetlerine erişimlerine de katkı sağlayacaktır. İkinci ve üçüncü basamak hizmetlerle ilişkili olarak da bu alanlardaki yoğunluğun azaltılması amacıyla aile hekimlerinden hizmet alımını hastalar için daha tercih edilir ve ulaşllabilir hale getirilmesi sağlanmalıdır. Özel ağız ve diş merkezleriyle anlaşmalar yapılarak, hizmet sundukları bölgelerdeki engelli hastalara belli bir sinırlama dahilinde muayene ve tedavi yapmaları gerekliliği getirilmelidir. Bu uygulama yasal düzenlemelerle de desteklenerek, 2 . ve 3 . basamak kamu kurumlarının yükü özel kurumlarla paylaştırılmış olacak, aynı zamanda da engelli bireylerin hizmete ulaşmaları desteklenmiş olacaktır. Çalışmada, yaşam olanakları daha da zor olan cezaevleri, çocuk sslah evleri, huzurevleri, korunmaya muhtaç çocukların barındığı çocuk yuvaları ve yetiştirme yurtları gibi bazılarında hekimin bulunmadığı toplu alanlarda engelli bireylerin sağlık hizmetlerinden faydalanabilmeleri içinde diş hekimlerinin, iş yeri hekimlerinin ve sertifika programını başarı ile tamamlamış yardımcı sağlık personellerinin de bu alanlarda görevlendirilmesi üzerine öneriler sunulmaktadır.

Tekerlekli sandalye kullanan ortopedik engelli bireylerin ağız ve diș sağlığına ilișkin sorunların çözümüne yönelik sağlık hizmetleri alanı dışında da yaşadıkları alanlara yönelik fiziksel düzenlemelerin sağlanması için başta merkezi ve yerel yönetimlerin ödüllendirme ve yaptırım önerileri ile Sivil Toplum Kuruluşları (STK), meslek örgütleri gibi diğer kuruluşlarla işbirliği içinde yürütülebilecekleri çalışma önerileri de sunulmaktadır. Engelli bireylere ve ailelerine yönelik eğitim, sosyal, kültürel, sanatsal ve sportif faaliyetlerin düzenlenmesi ve bunlar için online/dijital uygulamaların daha aktif halde kullanımının sağlanması da diğer öneriler arasındadır. Getirilen yasal düzenlemelerin denetim sisteminin etkin uygulanması amacıyla ekiplere ve yanı sıra engelli olmayan ve/veya yakın çevresinde engelli birey bulunmayanlara engelli bireylere yönelik farkındalık eğitimlerinin düzenlenmesine ilişkin öneriler de modelde yer alan uygulamalar arasındadır.

\section{SONUÇ}

Eğitim ve sağlık sistemi, bir ülkenin diğer tüm unsurlarını da etkileyen ve ülkenin refahı için en iyi organize edilmesi, sürekli geliștirilmesi ve en sorunsuz işlemesi gereken alanların başında gelmektedir. Bunu sağlamak amacıyla; sağlık sistemindeki sorunlar ölçülebilir verilerle net olarak belirlenmeli ve aynı şekilde sorunlara ilişkin bilimsel dayanakları olan çözümler üretilmelidir. Tespit edilen çözümlerin etkinliği ise yine ölçülebilir hedeflerle takip edilen dinamik bir yapıda olmalıdır.

Çalıșma konusunda yer alan ağız ve diş sağlığıyla ilgili sorunlar engelsiz bireylerde dahi yaşam 
kalitesini etkileyen kritik bir önem sahiptir. Ağız ve diş sağlığı sorunlarının beraberinde getirdiği sorunlar yaşam kalitesini olumsuz yönde etkilemekte olduğu araştırmalardan elde edilen sonuçlarda da görülmektedir (Cimilli ve ark., 2012). Bu sorunların aynı zamanda engelli bireylerde ortaya çıkması sorunları daha da karmaşık hale getirmektedir. $\mathrm{Bu}$ açıdan değerlendirilen, tekerlekli sandalye kullanan ortopedik engelli bireylerin ağız ve diş sağlığına yönelik hazırlanan model önerisinin, en önemli odağı; konunun fiziksel çevre, eğitim, sosyal, kültürel, sanatsal, sportif faaliyetler, ekonomik şartlar, STK'ları, politik çevre ve yasal düzenlemeleri kapsayan "bütüncül bir yaklaşımla" hazırlanmış olmasıdır.

Çalışmadan elde edilen bulgulara bakıldığında; engelli bireylerin ADSH'ne ilişkin en önemli sorunun toplum genelindeki farkındalık ve hassasiyet düzeyinin düşük olmasıyla ilişkili olduğu belirtilebilir. Sunulacak tüm hizmetlerin ve alınacak tüm tedbirlerin ancak konuyla ilgili farkındalığın ve hassasiyetin arttığı oranda etkili

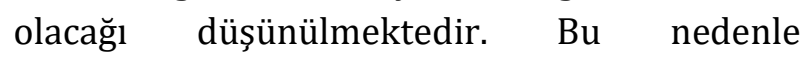
düzenlemelere, duyarlı bir eğitim modeli oluşturarak başlamak gerektiği belirtilebilebilir (Glick ve ark., 2012). Birinci basamağa entegre edilen ADSH için ASM'lerde hizmet sunan dişhekimleri ve yardımcılarının istihdamının sağlanması, engellilere yönelik evde bakım hizmetlerinin artırılması, bu alanda hizmet sunan "Engelli Bireylere Yönelik Sağlık Hizmetleri Sunumu Sertifika Programı" nı tamamlamış olan dişhekimleri ve yardımcılarının portatif ünit ve gezici araçlarla hizmet sunmaları, engelli bireylere yönelik kamu yükünün de azaltılması amacıyla özel ADSM ile anlaşmaların yapılması engellilerin ADSH'ne ulaşımlarında önemli aşamalar kaydedilmesini sağlayacak uygulamalardır.

Engelli bireylerin sorunlarına ilişkin farkındalığı artmış bir toplumda, sunulacak birinci basamağa entegre edilmiş ADSH'leri başta olmak üzere tüm sağlık hizmetleri, kamu alanlarındaki çevre ve hizmet sunum düzenlemeleri, yasal düzenlemeler, eğitim imkanları, psikolojik ve sosyal desteklerle bu alanla ilgili belirlenmiş ölçülebilir tüm hedeflere büyük ölçüde ulaşılmış ve engelli bireylerin ADSH'lerine erişimi etkin ve verimli hale getirilmiş olacağı belirtilebilir.

Çıkar Çatışması Bildirimi; Yazarların herhangi bir kişi ya da kuruluş ile çlkar ilişkisi bulunmamaktadır.

\section{KAYNAKLAR}

Birleşmiş Milletler Engellilerin Hakları Sözleşmesi (2008). http://www.ktood.org/BMengelli-haklari-yasasi.pdf. Erişim 13 Ocak 2021.

Buchholtz KJ, King RS (2012) Policy and proposals that will help improve access to oral care services for individuals With Special Health Care Needs. NC Medical Journal 73(2):124-127.

Cimilli H, Karaçaylı Ü, Şişman N, Kartal N, Mumcu G (2012) Comparison of the oral health related quality of life and dental pain in symptomatic irreversible pulpitis and pericorontis. Journal of Dental Sciences 7:250-260.

Dental Quality Alliance Improving Oral Health Through Measurement (2019) American dental association on behalf of the dental quality alliance.

Glick M, Silva OM, Seeberger GK, Xu T, Pucca G, Williams DM, Kess S (2012) FDI Vision 2020: shaping the future of oral health. International Dental Journal 62:278-291.

İnan S, Peker GC, Tekiner S, Ak F, Dağlı Z (2013) Engellilik, Türkiye'de engellilerin durumu ve sağlık hizmet sunumuna bir bakış. TAF Preventive Medicine Bulletin 12(6).

Kalaycı S, Akın A (2019) Engellilere Yönelik yerel sosyal hizmetlerde belediyelerin yeri: Malatya Büyükşehir Belediyesi. Selçuk Üniverisitesi Sosyal Bilimler Meslek Yüksekokulu 22(2):663-674.

Karagöz N, Üstün S, Ilıman E (2019) Avrupa Ülkelerindeki gelişmeler işığında türkiye'de engelli evde bakım hizmetlerinin değerlendirilmesi: sivas ili örneği. Anemon Muş Alparslan Üniversitesi Sosyal Bilimler Dergisi 7(4) 279-291.

Mumcu G, Köksal L, Şişman N (2013) An analysis of oral health campaigns from a social marketing perspective. Galatasaray Üniversitesi İletişim Dergisi 3:53-73.

Oral Health Program Strategic Plan 2011 - 2014 (2011) National center for chronic disease prevention and health promotion. Centers for Disease Control and Prevention. 
Oredugba FA, Akindayomi Y (2008) Oral health status and treatment needs of children and young adults attending a day centre for individuals with special health care needs. BMC Oral Health 1472$6831 / 8 / 30$.

Özata M, Karip S (2017) Engelli bireylerin sağlık hizmetleri kullanımında yașadıkları sorunlar: Konya Örneği. Hacettepe Sağlık İdaresi Dergisi 20(4): 409427.

Özyürek A, Çınar M, Yavuz NF, Karadayı N (2014) Engelli çocuklarda ağız ve diş sağlığı problemleri. Uluslararası Aile Çocuk ve Eğitim Dergisi 4(2) 134148.

Sancaklı HŞ (2009) Özel bakım ihtiyacı olan bireylerde ağız diş sağlığı uygulamaları. İstanbul Üniversitesi Dişhekimliği Fakültesi Dergisi 43:1-2 3943.

Sirel B, Boyacıgil O, Duymuş H, Konaklı N, Altunkasa F, Uslu C (2012) Çukurova Üniversitesi yerleşkesi açı alanlarının fiziksel engelliler bakımından ulaşılabilirliğinin değerlendirilmesi. Çukurova Üniversitesi Mühendislik Mimarlık Fakültesi Dergisi 27(1):53-72.

T.C. Resmi Gazete (25 Ocak 2013) Aile Hekimliği Uygulama Yönetmeliği Sayı : 28539.

T.C. Resmi Gazete (07 Temmuz 2005) Engelliler Hakında Kanun Sayı : 25868.

T.C. Resmi Gazete (14 Temmuz 2009) Milletlerarası Sözleșme, Engellilerin Haklarına İlişkin Sözleşme Sayı : 27288.

https://humanrightscenter.bilgi.edu.tr/media/uploa ds/2015/08/03/EngellilerinHaklarinaIliskinSozles me.pdf, Erişim: 06 Ocak 2021.

Türk Dişhekimleri Birliği (2020) Dişhekimliğinde İnsangücü planlaması 2020.

http://tdb.org.tr/tdb/v2/ekler/Dishekimliginde_Ins angucu_Planlamasi_2020.pdf. Erişim: 13 Ocak 2021.

Türk Dişhekimleri Birliği. Engellilerde Ağız ve Diş Sağlığı Broşürü.

http://www.tdb.org.tr/tdb/dosya/engelli.pdf

Erişim: 11 Ocak 2021.

TÜİK, Türkiye Engelliler Araştırması, 2002. http://www.tuik.gov.tr/PreTablo.do?alt_id=1017

Erișim Tarihi: 11 Ocak 2021.

TÜİK, Türkiye Engellilerin Sorun ve Beklentileri Araştırması, 2010.

http://www.tuik.gov.tr/PreTablo.do?alt_id=1017

Erișim Tarihi: 11 Ocak 2021.
Vozza L (2015) Preventive strategies in oral health for special needs patients. Annali di Stomatologia VI (3-4): 96-99.

Oral Health Coalition of Alabama (2018). Your mouth your health the connection of oral health to overall health. a state oral health plan for all alabamians 2018-2023. Alabama Department of Public Health Oral Health Office.

http://alabamapublichealth.gov/oralhealthcoalition /assets/alsohp.pdf Erişim: 12 Ocak 2021. 